\title{
Squamous Cell Carcinoma of the Larynx Arising in the Intracordal Cyst
}

\author{
Seon-Gyu Lee ${ }^{1}$ (D) Min Jeong Song ${ }^{2}$ (D), Young-Gyu Eun ${ }^{1}$ (D) and Young Chan Lee ${ }^{1}$ (D) \\ 'Department of Otorhinolaryngology-Head and Neck Surgery, School of Medicine, Kyung Hee University, Seoul, Korea \\ 2Department of Pathology, Kyung Hee University Hospital at Gangdong, School of Medicine, Kyung Hee University, Seoul, Korea
}

\section{성대 낭종 내부에 발생한 후두 편평세포암종}

이선규 ${ }^{1}$, 송민정 2 , 은영규 ${ }^{1}$, 이영찬 ${ }^{1}$

경희대학교 의과대학 이비인후과학교실, ${ }^{1}$ 경희대학교 의과대학 강동경희대학교병원 병리학교실2

More than half of patients presenting with hoarseness show benign vocal cord changes. However, in rare cases with benign mucosal lesions, it can be diagnosed as a malignant disease after histopathological examination. A 53-year-old man with a 30-pack-year smoking history was admitted for the evaluation of hoarseness, and using a laryngoscope, an enclosed, sac-like cystic lesion was detected on the midpoint of the right true vocal cord. The cystic lesion was deemed to be an intracordal cyst and treated with laryngeal microsurgery. However, pathological findings showed squamous cell carcinoma of the larynx arising in the intracordal cyst, which is exceptionally rare. Therefore, even if a benign lesion is initially suspected, a biopsy must be performed on a patient with smoking history to confirm the diagnosis. In conclusion, we report a case of squamous cell carcinoma of the larynx arising in the intracordal cyst.

Keywords Squamous cell carcinoma; Larynx; Intracordal cyst.

\section{서 론}

애성(hoarseness)을 주 호소로 내원하는 환자의 절반 이상이 성대의 양성 병변으로 진단되지만 반드시 악성 종양, 선천성 기형, 염증, 신경의 이상 등도 감별되어야 한다[1]. 성대 폴립, 성대 결절, 라인케 부종, 성대 낭종 등의 양성 점막 질환은 병변이 작고 표면 이 매끈하며 경계가 명확한 특징이 있으며 후두경 검사와 후두 스트로보스코피를 통해 악성 종양과 감별해야 한다[2]. 일반적으로 혈관구조(vasculature), 외번형(exophytic) 병 변, 궤양성(ulcerative) 병변은 악성 가능성을 시사하지만 정확한 진단을 위해서는 조직 병리검사가 동반되어야 한다[2,3].

성대 낭종은 성대 폴립, 결절, 라인케 부종 등 다른 양성 점막 질환에 비해 그 빈도는 적지만 상대적으로 이중음(diplophonia), 발성제한(voice limitation) 등 심한 음성 변화 를 일으킨다. 또한 다른 양성 점막 질환과 감별이 힘들어 조직병리검사를 통해 진단되는 경우가 많다[4]. 조직병리학적으로 성대 낭종은 중층의 편평상피로 둘러싸인 유표피종
Received November 5, 2020

Revised November 17, 2020

Accepted November 26, 2020

\section{Corresponding Author}

Young Chan Lee, MD, PhD

Department of Otorhinolaryngology-

Head and Neck Surgery,

School of Medicine,

Kyung Hee University,

892 Dongnam-ro, Gangdong-gu,

Seoul 05278, Korea

Tel +82-2-440-6257

Fax+82-2-440-7336

E-mail medchan@hanmail.net

\section{ORCID iDs}

Seon-Gyu Lee (D)

https://orcid.org/0000-0002-1313-5620

Min Jeong Song (D)

https://orcid.org/0000-0002-5891-4329

Young-Gyu Eun (iD)

https://orcid.org/0000-0003-4081-5207

Young Chan Lee iD

https://orcid.org/0000-0001-5577-7288

This is an Open Access article distributed under the terms of the Creative Commons Attribution Non-Commercial License (https://creativecommons.org/ licenses/by-nc/4.0) which permits unrestricted non-commercial use, distribution, and reproduction in any medium, provided the original work is properly cited. 
(epidermoid cyst)과 점액성 상피로 둘러싸인 저류낭 $(\mathrm{mu}-$ cous retention cyst)으로 분류하며, 저류낭이 유표피종보다 더 흔하게 발생하는 것으로 알려져 있다. 유표피종은 이학적 검사상 흰색을 띠고 보다 반짝거리는 양상을 보여 술 전에 성 대 폴립이나 결절 등으로 오인되는 경우가 적으나, 저류낭의 경우 유표피종에 비해 색깔이나 양상이 뚜렷하지 않아 성대 폴립, 혹은 성대 부종으로 오인되는 경우가 많다[5]. 형태학적 구분에 있어 한계가 있기 때문에 성대 낭종으로 의심되었던 병 변이 조직병리검사상 다른 양성 점막 질환으로 진단되는 경 우는 비교적 흔하나 성대 낭종을 포함한 양성 점막 질환이 악 성 종양과 함께 진단되는 경우는 극히 드물다. 본 저자들은 후두경 검사, 후두 스트로보스코피상 성대 낭종 소견을 보여 후두미세수술을 시행하였으나 최종 조직병리검사상 성대 낭 종 내부에서 편평세포암종이 함께 발생한 증례를 체험하였기 에 문헌 고찰과 함께 보고하고자 한다.

\section{증 례}

53세 남자 환자가 1달 전부터 시작된 애성을 주소로 내원하 였다. 환자는 30 갑년의 흡연력이 있었으며 음주력은 없었고 직 업상 음성 남용력이 있었다. 후두경 검사상 우측 진성대 중반 $1 / 2$ 지점에서 약 2 3 mm의 단일 낭종 형태의 종물이 관찰되 었으며(Fig. 1), 주위의 후두개(epiglottis), 양측 이상와(pyriform sinus), 피열연골(arytenoid cartilage) 등에서는 이상 소 견이 관찰되지 않았다. 후두 스트로보스코피상 종물 부분에 서 점막의 파동이 단절되는 성대 낭종에 부합되는 소견이 나 타났다. 음성 검사상 기본주파수 $118.606 \mathrm{~Hz}$, 주파수 변동률 $7.77 \%$, 진폭 변동률 $13.65 \%$, 잡음 대 조화음비 0.927 이었다. 전신마취하에 후두미세수술을 시행하였고 병변 외측에 성대

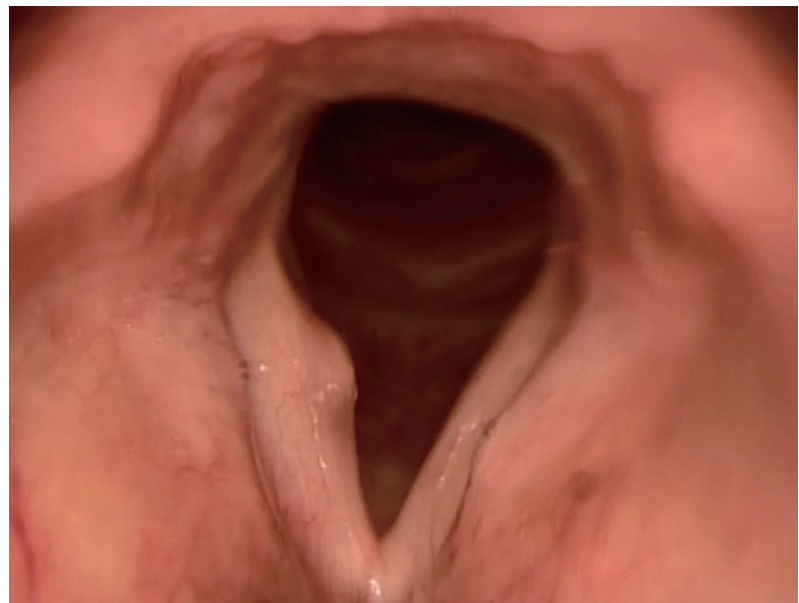

Fig. 1. Laryngoscopic finding. A Initial laryngoscopy showed single smooth-surfaced lesion of right vocal cord.
의 자유연과 평행하게 절개를 넣어 미세피판을 들어 올린 후 성대 점막은 보존하며 성대 내 낭종을 노출하였다. 피판을 들 어올리면서 비교적 경계가 명확한 낭종 형태의 종물을 제거하 였으며 성대 점막 피판을 보존하여 수술을 종료하였다(Fig. 2). 술 후 조직병리검사상 성대 낭종 내부에 케라틴을 형성하는 비정형 편평상피세포들이 관찰되어 고분화형 편평세포암종 (well-differentiated squamous cell carcinoma)으로 진단되 었다(Fig. $3 \mathrm{~A}$ ). 이후 병기 진단을 위해 양전자방출단층촬영과 경부 전산화단층촬영을 실시하였으며 경부 임파선 및 다른 장기로의 전이 소견은 보이지 않아 병기는 1기(TlaNOM0)였 다. 잔여 편평세포암종의 근치를 위해 2 주 뒤 이산화탄소 레 이저를 이용한 성대절제술(laser cordectomy type III)을 시 행하였으며 술 후 조직병리검사상 절제 변연의 침범은 없었으 며 절제 조직에서는 상피 내 편평상피암종(squamous cell carcinoma in situ)이 관찰되었다(Fig. 3B). 술 후 6개월간 외래 통해 재발 소견 없이 경과 관찰 중이다.

\section{고 찰}

애성의 원인은 감기부터 악성 종양까지 매우 다양하다[6]. 임상에서 시행되는 후두경 검사는 진단에 큰 도움을 주며 일 반적으로 종물의 크기가 작고 표면이 매끈하고 경계가 명확하 면 양성 점막 질환을 의심해야 하며 혈관구조, 외번형 병변, 궤양성 병변이 보이면 악성 종양을 의심해야 한다[2,3]. 또한 백반증(leukoplakia), 각화증(keratosis), 유두종증(papillomatosis)은 대표적인 전암성 병소이며 각각 형태학적 특징이 있어 다른 병변과 육안적으로 구분할 수 있다[6]. 성대 종물의

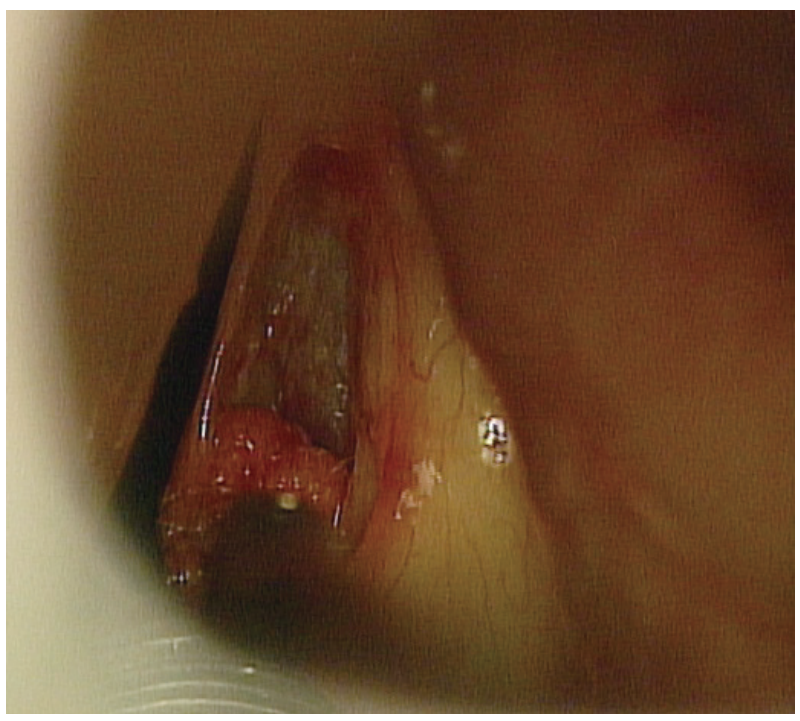

Fig. 2. Intraoperative finding. The mucous membrane of right true vocal cord is preserved and the cyst in the vocal cord was removed. Laryngoscopic microsurgery was performed. 

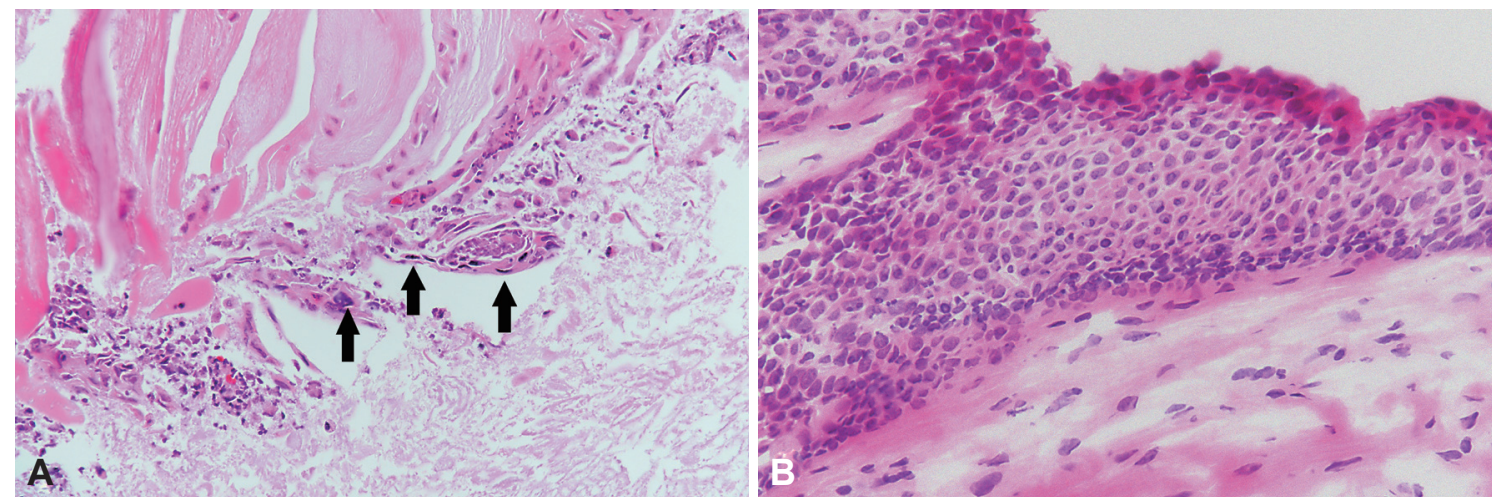

Fig. 3. Histopathologic findings (hematoxylin and eosin staining, $\times 400$ ). A: Microscopically, keratinizing atypical squamous cells with nuclear pleomorphism, hyperchromasia and high nucleus/cytoplasm ratio are scattered in necrotic background. Arrows indicate dysplastic squamous epithelial cells. B: In cordectomy specimen, the hyperplasic epithelium shows disordered stratification and polarity. The dysplastic squamous epithelial cells are occupying entire thickness of epithelium.

확진은 조직병리학적 검사를 통해 이루어지지만 성대의 양성 점막 질환과 악성 종양은 일차적으로 후두경 검사, 후두 스트 로보스코피를 통해 구분할 수 있다.

실제로 후두경 검사, 후두 스트로보스코피상 성대 양성 점막 질환이 의심되었는데 조직병리검사를 통해 악성 종양으 로 진단된 예는 드물다. 특히 성대 낭종에서 편평세포암종이 발생한 증례는 국내외에 아직 보고된 바 없다. 악성 종양 중 후두 육종양 상피암(sarcomatoid carcinoma)은 대부분 폴립 양(polypoid) 또는 유경형(pendunculated) 양상을 보이며 성대 침범 시 성대 폴립처럼 보일 수 있어 성대 폴립으로 오인 된 증례가 보고된 바 있다[7].

본 증례에서 환자는 30 갑년의 흡연력과 음성의 과도한 사 용 과거력이 있었으며 진성대에서 단일 낭종 형태의 종물이 관찰되었다. 형태학적으로 성대에서의 돌출이 미미하고 후두 스트로보스코피상 낭의 형태를 뚜렷하게 보이며 환자가 음성 남용력이 있어 성대 낭종으로 판단하고 후두미세수술을 시행 하였다. 하지만 조직병리검사상 성대 낭종 내부에 고분화형 편평세포암종이 관찰되었다. 본 증례는 성대 낭종으로 보이 는 양성 병변 내부에서 고분화형 편평세포암종인 악성 종양 이 동반된 임상적으로 중요한 보고로 사료된다. 본 증례를 토 대로 흡연력이 있는 환자에서는 성대 종물 발생 시 단일 종물 로 크기가 작고 표면이 매끈하며 경계가 명확하더라도 편평세 포암종 등의 후두 악성 종양의 가능성을 완전히 배제해선 안 되며 생검 및 조직병리학적 특징에 따른 면밀한 진단이 필요 할 것이다.
중심 단어: 편평세포암종, 후두, 성대낭종.

Acknowledgments

None.

Conflicts of Interest

The authors have no financial conflicts of interest.

\section{Authors' Contribution}

Conceptualization: Seon-Gyu Lee, Young-Gyu Eun, Young Chan Lee. Supervision: Young-Gyu Eun, Young Chan Lee. Writingoriginal draft: Seon-Gyu Lee, Min Jeong Song, Young Chan Lee. Writing-review \& editing: Young-Gyu Eun, Young Chan Lee. Approval of final manuscript: all authors.

\section{REFERENCES}

1. Roy N, Merrill RM, Gray SD, Smith EM. Voice disorders in the general population: prevalence, risk factors, and occupational impact. Laryngoscope 2005;115(11):1988-95.

2. Bohlender J. Diagnostic and therapeutic pitfalls in benign vocal fold diseases. GMS Curr Top Otorhinolaryngol Head Neck Surg 2013;12: Doc01.

3. House SA, Fisher EL. Hoarseness in adults. Am Fam Physician 2017; 96(11):720-8.

4. Nam SY, Song YJ. The efficacy of voice and stroboscopic analysis in diagnosis of vocal cyst. Korean J Otorhinolaryngol-Head Neck Surg 2000;43(4):411-5.

5. Nam SY. Benign mucosal disease of the larynx. In: Korean Society of Otorhinolaryngology-Head and Neck Surgery, editor. Otorhinolaryngology-head and neck surgery: head and neck. 3rd ed. Paju: Koonja; 2018. p.903-10.

6. Mau T. Diagnostic evaluation and management of hoarseness. Med Clin North Am 2010;94(5):945-60.

7. Kim TH, Lee GJ, Sohn JH. A case of sarcomatoid carcinoma of the larynx mimicking vocal polyp. J Korean Soc Laryngol Phoniatr Logop 2017;28(2):128-30. 